Published as: Witlox, F., B. Derudder \& V. Van Acker (2013) "Transport geography in

Belgium". Journal of Transport Geography, vol. 29, pp. 108-110.

\title{
Transport Geography in Belgium
}

Reviewing existing transport research in Belgium implies having some knowledge on how Belgium is organized and structured, given the close links between research, policy, and funding. As a federal state, Belgium is composed of three language communities (Flemish, French and German-speaking) and three regions (Flemish region, Walloon region and Brussels-Capital region), each of which independently exercise their authority within their domains. The federal state deals with nationwide authorities such as justice, social security, foreign affairs, public health, nuclear energy, finance and monetary policy. Transport (apart from the National Railways, the North Sea and the traffic code) is, since the third state reform of 1988-1989, no longer a centralized authority. It has been transferred, together with e.g. public works, spatial planning and housing, to the regional level. The communities exercise their authority only within linguistically determined geographical boundaries and mainly relate to language and cultural (education, media) issues. Here, the link with transport is almost non-existent. Hence, today, the most important transport authorities are situated at the regional level.

Although the regions have become more and more involved in setting Belgium's transport research agenda, for the past 20 years, this task was primarily reserved for the Belgium Science Policy Office (www.belspo.be). Belspo aimed to implement national and international multiannual research actions with a view to consolidate Belgium's scientific and technological potential. Since its foundation in 1991, about 562 projects were initiated, of which 112 projects dealt with transport and mobility, covering almost every aspect of the research domain, ranging from passenger transport (i.e., public transport, walking/bicycles, intermodal passenger transport, private and company passenger cars, urban road transport, mobility management, and traffic management), to freight transport and logistics (intermodal freight transport, all modes of transport, city logistics), to transport technology (renewable energy, alternative fuels, environmentally friendly vehicles) (Macharis and Toint, 2012). The Belspo research initiatives have been very important for generating Belgian partnerships and networks, forming specialism and creating expert knowledge pools. In a way, Belspo can be considered as having largely contributed to the present-day transport and mobility academic and institutional research landscape. For the purpose of trying to create a Belgian Mobility Research (BeMoR) network, van Geelen (2009) has made an inventory of the most important players and also tried to pinpoint specific research domains.

At the national level, besides the Belspo initiated research, the Federal Plan Bureau (FPB) has expertise in the development and analysis of transport indicators and long term transport projections. The FPB also uses and develops the long term transport model 'PLANET' (long-run prospects of transport activities, environmental impact and welfare) and a general equilibrium model which looks at the interaction between economy and transport. Apart from the FPB, the Belgian Road Research Centre (BRRC), the Belgium Institute for Traffic Safety (BIVV) and B-Mobility (NMBS-SNCB) are noteworthy institutions. At the regional level, important players in commissioning and/or executing transport and mobility research are organizations like VITO (Flanders Institute for Technology Development), VIL (Flanders Institute for Logistics), VIM (Flanders Institute for Mobility), Flemish Foundation for Traffic Knowledge (VSV), TML (Transport \& Mobility Leuven), Logistics in Wallonia, and the Centre Interuniversitaire d'Etude de la Mobilité (CIEM). Also important in Flanders are the third-generation policy research centers approved by the Flemish Government on "Commodity and Passenger Flows" (coordinated by the University of Antwerp), on "Traffic Safety" (coordinated by Hasselt University) and on "Spatial Development" (coordinated by Ghent University and the KU Leuven). A comparable initiative, known as Marshall Plan 2.Green, exists for the Walloon area to promote research and innovation, in close linkage with enterprises.

But clearly the most relevant and productive scientific contributions stem from the academic community. In Flanders, leading transport, logistics and mobility researchers are Bruno De Borger (pricing and transport policy), Theo Notteboom (ports), Wouter Jacobs (port-city relationships), Wout Dullaert (logistics), Eddy Van de Voorde (freight, air, ports), Hilde Meersman (freight modeling) and Ann Verhetsel (commuting), all at the University of Antwerp (including ITMMA). At the Free University of Brussels, there is Cathy Macharis (intermodal transport, multi-criteria analysis), Joeri van Mierlo (electric vehicles) and Michael Dooms (ports). At the KU Leuven prominent scholars are Stef Proost (pricing and transport policy), Thérèse Steenberghen (spatial planning, tourism) and Chris Tampère (traffic flows and infrastructure). At Ghent University, there is Frank Witlox (travel behavior modeling, city logistics), Ben Derudder (business travel, air transport), Nico Van de Weghe (moving 
objects and GIS), Georges Allaert (spatial planning), Dirk Lauwers (traffic engineering) and Birger Raa (logistics). At Hasselt University the main academics are Geert Wets (traffic modeling), Tom Brijs (traffic safety), Davy Janssens (activity-based modeling), Patrick De Groote (tourism), An Caris (network logistics) and Gerrit Janssens (logistics). Turning to Wallonia, there is Bart Jourquin and Michel Beuthe (freight modeling) from the UCL Mons, Jacques Charlier (ports), Isabelle Thomas (spatial modeling) and Jacques-François Thisse (spatial econometrics) at UC Louvain, Sabine Limbourg (logistics and supply chain management), Mario Cools (activity-based modeling) and Jacques Teller (town planning) at the University of Liege, Michel Hubert (sociology and mobility) at the Facultés universitaires Saint-Louis in Brussels, and Eric Cornelis and Philippe Toint (transport system modeling) at the University of Namur.

Four remarks need to be made here. First, not all people listed here are transport geographers -in fact most of them are not- but they are all involved in transport/logistics/mobility-oriented research. Second, the list contains only tenured university staff members, and does not give due credit to the large number of post-doc researchers that are also doing cutting-edge research. Third, there are also Belgian transport researchers that work outside Belgium (e.g., Jean-Claude Thill at UNC Charlotte, Luc Anselin at Arizona State University, Frederic Dobruszkes at University of Oxford); and fourth, there are numerous people who are active in operations research, econometrics, regional science, landscape research, environmental economics, civil engineering, urban studies, etc. with whom also joint transport and transport-related research is realized.

In an attempt to pinpoint what have been the major research topics and contributions stemming from Belgianbased researchers in the field of transport geography over the last five years, we conducted a web-of-science search using "transport*", "mobilit*" and "logistics" as keywords, in the research areas "transportation", "geography" and "urban studies" in the time frame "2007-2012", with "Belgium" in the address of one of the authors. This resulted in about 400 contributions, which we then ranked according to times cited to have an idea of the impact of the papers.

Not surprising, a huge variety of subjects is treated, but some specialism can be found. Relating to passenger transport and mobility we notice a series of paper that focus on commuting issues. Commuting is analyzed in relation to biking and rail transport, developing a commute-energy performance index, looking at the persuasiveness of free public transport, developing mobility management strategies, and analyzing traffic flows (e.g. Boussauw et al., 2011; De Witte et al., 2008). Another large strand of papers relate to issues of space-time geography and social exclusion and equity, mapping (joint) accessibility measures, studying the relationship between land-use and transport planning, examining urban travel behavior modeling and lifestyles, and developing new activity-based modeling approaches and data collection methods (e.g., Witlox, 2007; Neutens et al., 2012; Van Acker et al., 2011; Kusumastuti et al., 2011; Cirillo et al., 2012). Turning to freight transport there are papers focusing on the importance of quality attributes in modal shift analysis, analyzing the potential of horizontal cooperation in logistics, developing rail-road container terminal location models, examining the role of terminals in port/hinterland logistical relationships, and putting forward a transport risk analysis of hazardous substances (e.g., Caris et al., 2008; Limbourg and Jourquin, 2010; Zamparini et al., 2011). There are also a number of papers on air transport, looking at the effects of (new) low cost carrier introduction, of liberalization, and of the economic crisis on air transport, and on ports (e.g., Dobruszkes, 2009). In respect to transport technology and traffic safety papers can be found on alternative fuel use and clean technologies, and on the acceptability of ITS (e.g., Vlassenroot et al., 2007), but also a series of papers relating to the effects of seat belt use, exposure risks to black carbon, effects of sign repetition, crashes at roundabouts, etc. Topics related to pricing and transport policy include the analysis of strategic investments in infrastructure, the search for optimal (government) pricing strategies, analyzing the effects of subsidies and tax treatment in transport, and focusing on the effects of road pricing. Here the work of Stef Proost and Bruno De Borger is very prevailing (e.g., De Borger and Proost, 2012). Several papers also focus on the analysis of networks at different geographical scales. This has led to the development of papers on regional port systems, maritime networks, global/world city network formation, and /or the analysis of hub port configuration (e.g., Derudder and Witlox, 2008; Jacobs and Notteboom, 2011). Part of these novel research avenues stems from the work of young, promising post-doc transport geographers.

In a sense there are no real major research issues that are not being treated by Belgian researchers, at least not if we were to compare this to transport and transport-related research being conducted in for instance the Netherlands, Germany or other neighboring countries. Belgium researchers also tend to work/co-publish more with foreign researchers. And Belgium researchers are also usually present at major scientific events and conferences such as the AAG, ERSA, IAME, IATBR, IGU, RGS/IBG, TRB, and WCTR. At a more national level the BIVEC-GIBET Transport Research Days (www.bivec.eu) is a welcomed event. 
A noticeable, but also detrimental trend however is that less research is being done whereby Belgium is taken as a case study, in favor of the regional (i.e., Flemish, Walloon or Brussels) level. A number of studies exist in which Flanders (and then often without the Brussels Capital region) is taken as case study. Clearly, this is a problem, given that commuting zones, train movements, hinterland transport, or air transport do not stop at the regional border, but cross the regional and national borders. Often data availability and compatibility problems, possibly language issues, and/or the lack of a national, Belgian scientific research foundation might be accountable. A few exceptions however do exist whereby research groups from different regions team up to analyze Belgian transport geography problems (Vandenbulcke et al., 2009; Vandenbulcke et al., 2011; Dujardin et al., 2012; Van Malderen et al., 2012; Vanoutrive et al., 2012a, 2012b).

\section{References:}

Boussauw, K., T. Neutens \& F. Witlox (2011) "Minimum commuting distance as a spatial characteristic in a non-monocentric urban system: the case of Flanders”. Papers in Regional Science. Vol. 90 (1), pp. 47-66.

Caris, A., C. Macharis \& G.K. Janssens (2008) "Planning problems in intermodal freight transport: Accomplishments and prospects". Transportation Planning and Technology. Vol. 31 (3), pp. 277-302.

Cirillo, C., E. Cornelis \& P. Toint (2012) “A model of weekly labor participation for a Belgian synthetic population”. Networks \& Spatial Economics. Vol. 12 (1), pp. 59-73.

De Borger, B. \& S. Proost (2012) “A political economy model of road pricing”. Journal of Urban Economics. Vol. 71 (1), pp. 79-92.

De Witte, A., C. Macharis \& O. Mairesse (2008) "How persuasive is 'free' public transport? A survey among commuters in the Brussels Capital Region”. Transport Policy. Vol. 15 (4), pp. 216-224.

Derudder, B. \& F. Witlox (2008) "Mapping world city networks through airline flows: context, relevance, and problems". Journal of Transport Geography. Vol. 16 (5), pp. 305-312.

Dobruszkes, F. (2009) "New Europe, new low-cost air services”. Journal of Transport Geography. Vol. 17 (6), pp.423-432.

Dujardin, S., K. Boussauw, F. Brévers, J.-M. Lambotte, J. Teller \& F. Witlox (2012) "Sustainability and change in the institutionalised commute in Belgium: exploring regional differences". Applied Geography. Vol. 35 (1-2), pp. 95-103.

Jacobs, W. \& T. Notteboom (2011) "An evolutionary perspective on regional port systems: the role of windows of opportunity in shaping seaport competition”. Environment and Planning A. Vol 43 (7), pp.1674-1692.

Kusumastuti, D., E. Hannes, B. Depaire, K. Vanhoof, D. Janssens, G. Wets \& B.G.C. Dellaert (2011) “An interactive computer-based interface to support the discovery of individuals' mental representations and preferences in decisions problems: An application to travel behavior". Computers in Human Behavior. Vol. 27(2) 997-1011.

Limbourg, S. \& B. Jourquin (2010) "Market area of intermodal rail-road container terminals embedded in a huband-spoke network". Papers in Regional Science. Vol. 89 (1), pp. 135-154.

Macharis, C. \& Ph. Toint (2012) Transport and Mobility: 20 years of Scientific Research in Belgium. Brussels: Belgian Science Policy.

Neutens, T., M. Delafontaine, T. Schwanen \& N. Van de Weghe (2012) "The relationship between opening hours and accessibility of public service delivery”. Journal of Transport Geography. Vol. 28, pp. 128-140.

Van Acker, V., P.L. Mokhtarian \& F. Witlox (2011) “Going soft: On how subjective variables explain modal choices for leisure travel”. European Journal of Transport and Infrastructure Research. Vol. 11 (2), pp. 115-146.

van Geelen, H. (2009) BeMoR net - Belgian Mobility Research network. Haalbaarheidsstudie naar een platform voor wetenschappelijk overleg over het Belgische transport- en mobiliteitsonderzoek. Brussels: Belgian Science Policy. 
Van Malderen, L., B. Jourquin, I. Thomas, T. Vanoutrive, A. Verhetsel \& F. Witlox (2012) "On the mobility policies of companies: what are the good practices? The Belgian Case”. Transport Policy. Vol. 21, pp. 10-19.

Vandenbulcke, G., C. Dujardin, I. Thomas, B. de Geus, B. Degraeuwe, R. Meeusen, \& L. Int Panis (2011) "Cycle commuting in Belgium: Spatial determinants and 're-cycling' strategies". Transportation Research Part A. Vol. 45 (2), pp. 118-137.

Vandenbulcke, G., T. Steenberghen \& I. Thomas (2009) "Mapping accessibility in Belgium: a tool for land-use and transport planning?”. Journal of Transport Geography. Vol. 17 (1), 39-53

Vanoutrive, T., E. Van de Vijver, L. Van Malderen, B. Jourquin, I. Thomas, A. Verhetsel \& F. Witlox (2012a)

"What determines carpooling to workplaces in Belgium: location, organisation, or promotion". Journal of Transport Geography. Vol. 22 (1), pp. 77-86.

Vanoutrive, T., L. Van Malderen, B. Jourquin, I. Thomas, A. Verhetsel \& F. Witlox (2012b) "Rail commuting to workplaces in Belgium: a multilevel approach". International Journal of Sustainable Transportation. Vol. 6 (2), pp. 67-87.

Vlassenroot, S., S. Broekx, J. De Mol, L. Int Panis, T. Brijs \& G. Wets (2007) "Driving with intelligent speed adaptation: Final results of the Belgian ISA-trial”. Transportation Research A. Vol. 41 (3), pp. 267-279.

Witlox, F. (2007) "Evaluating the reliability of reported distance data in urban travel behaviour analysis". Journal of Transport Geography. Vol. 15 (3), pp. 172-183.

Zamparini, L., J. Layaa \& W. Dullaert (2011) "Monetary values of freight transport quality attributes: A sample of Tanzanian firms". Journal of Transport Geography. Vol. 19 (6), pp. 1222-1234.

Frank Witlox*, Ben Derudder \& Veronique Van Acker

Ghent University

Krijgslaan 281, S8, 9000 Gent

Belgium

E-mail address: frank.witlox@ugent.be, ben.derudder@ugent.be, veronique.vanacker@ugent.be

*corresponding author 